\title{
The role of management support on innovativeness in the Nigerian Entrepreneurial businesses
}

\author{
OMANKHANLEN ALEXANDER EHIMARE \\ Department of Banking and Finance \\ Covenant University, Ota, Ogun State \\ NIGERIA \\ OGAGA-OGHENE O. JOSHUA \\ Vice-Chancellor's Office \\ Covenant University, Ota, Ogun State \\ NIGERIA \\ NKWODIMMAH C. PASCAL \\ Department of Banking and Finance \\ Covenant University, Ota, Ogun State \\ NIGERIA
}

\begin{abstract}
The absence of a management supported ambience for innovativeness is a problem affecting required growth in sales volume and income in Nigerian businesses. A significant proportion of companies in the industry are ailing and struggling to survive. This study examined the role of management support on innovativeness in Nigerian Entrepreneurial Businesses. Survey research design was adopted for the study. The population was 5,362 full time employees of selected flour milling companies in Nigeria. A sample size of 372 was selected using stratified sampling and simple random sampling techniques. A validated questionnaire was used for data collection. Cronbach's Alpha coefficients for the construct ranged from .708 to .847 and the response rate was $81.72 \%$. Data were analyzed using descriptive and inferential statistics (mean, standard deviation, and simple regression analysis). The findings showed that management support has positive effect on innovativeness $(\mathrm{F}(1,302)=188.671, \mathrm{p}<0.01), \mathrm{R}=.620, \mathrm{R}^{2}=.385$, Adj $\mathrm{R}^{2}=.381$, and estimated coefficient .620; The study concluded that management support has a significant positive effect on innovativeness in Nigerian Businesses. The study recommended that management should nurture an organizational management support that encourages entrepreneurial behaviour by making organizational design and development a continuous focus.
\end{abstract}

Keywords: Corporate entrepreneurship, Innovativeness, Management support, Organizational climate, Organizational Climate.

Received: October 10, 2019. Revised: March 27, 2020. Re-revised: April 6, 2020.

Accepted: April 24, 2020. Published: April 27, 2020.

\section{Introduction}

According to Scott and Bruce [27], employees' perception of organizational support for innovation in the current era of emphasis on creativity and innovation would lead to the creation of pro-innovation organizational climate. In the same vein, perceived organizational support of innovative actions, communicates organizational values and norms in respect of image gains or risks and can influence the innovative work behavior of employees, because the work environment has high tolerance for trial and error (Scott \& Bruce [27]; Yuan and Woodman, [30]. Thus, a proinnovation climate encourages employees to 
initiate necessary and beneficial changes in organizational life.

There seem to be a consensus in literature that organizational climate can change and intensify individual attitudes and behaviors towards accomplishing organizational goals (Kang et al., [10]; Probst, [23]. Imran, Saeed, Anis-ul-Haq, and Fatima [9] argued that organizational climate that facilitates and supports creativity and innovative employee behavior is a prerequisite for sustainable competitive advantage as well as organizational success. But, unbridled pro-innovation climate could lead to undesirable consequences for an organization such as inefficiency, frustration, increased cynicism, decreased functional expertise learning possibilities, delay and increased costs, distortion of work boundaries, invasion of private life, stress, innovation resistance and role conflict, Aggeri and Segrestin [2]; Rangarajan, Jones and Chin [24].

\subsection{Statement of the Problem}

One of the critical challenges flour milling companies in Nigeria are experiencing is slow sales growth Ikon and Nwankwo, [8]. This is despite the prospects of higher turnover in a business environment where demographic indicators suggest that demand for flour and flour-based products would be on the increase, due to growth in population and urbanisation KPMG, [13]. But, the leadership styles of Nigerian companies have been an issue of concern due to its adverse impact on the ability of employees to engage in entrepreneurial activities, such as innovativeness. According to Olughor [21], the management style of most Nigerian companies fosters employee indifference, which inhibits employee innovative behaviour. The Nigerian work setting has been described as impersonal and task oriented and is averse to employee involvement and creativity (Oke and Dawson, 18]; Tsado \& Gunu, [28].

The absence of a management supported ambience for innovativeness is a problem affecting required growth in sales volume and income in flour milling companies in Nigeria. A significant proportion of companies in the industry are ailing and struggling to survive as four out of the twenty-one companies in the industry accounts for over $70 \%$ of the flour market KPMG [13], and sales volume is a critical success factor in the industry for continuous survival and growth Njoku and Kalu, [17]. Therefore, it is vital to examine the effect of management support on innovativeness in selected flour milling companies in Nigeria, because this could help to resolve the problem of slow growth in sales and revamp ailing flour milling companies. Innovation, according to Okoye, Omankhanlen, Okoh and Areghan [19] refers to an idea, practice, or object which an individual or other unit of adoption perceives to be new

\subsection{Research Questions}

This study sought to answer the following questions:

1. What is the effect of management support on innovativeness in the selected flour milling companies in Nigeria?

\subsection{Objective of the Study}

1. To determine the effect of management support on innovativeness in the selected flour milling companies in Nigeria.

\subsection{Hypotheses}

The following null hypotheses were formulated for testing:

$\mathbf{H}_{\mathbf{0}}$ : Management support does not have a significant effect on innovativeness in the selected flour milling companies in Nigeria.

\section{Literature Review \\ 2.1 Management Support}

The support of management enables employees to accomplish their desires for empowerment, develop personality, achievement, and increase self-efficacy (Abrell, Rowold, Weibler, and Moenninghoff [1]; Ryan and Tipu, [26] Organisations are able to perceive current exploitable market conditions by encouraging corporate entrepreneurial actions and the establishment of a very conducive work climate through open communication and networking, supported by resource management practices, Van Wyk and Adonisi, [29].Based on the foregoing, management support is conceptualised in this study as the perceivedintent of top management to willfully 
avail organisational members with the requisite encouragement and resources to engage in creative and innovative behaviour in the organisation's quest for competitive advantage.

\subsection{Innovativeness}

Karimi and Walter [11] conceptualised innovativeness as a commitment of the company to continuously create new products/services, production processes, and organisational systems with emphasis on development in technology. Again, it is defined as a firm's receptivity and propensity to adopt new ideas that lead to development and launch of new products, processes, materials and resources, markets and organisational forms (Atalay et al., [4]; Rubera and Kirca, [25]. Top managers are responsible for strategic decision making and long-term goals. To perform management entrepreneurial innovation in the current era of globalization, firms use different approaches. However, out of many approaches, Management support has deemed a significant factor especially in emerging markets, Kra'snicka, Głód, Wronka-Po'spiech, [14]

\subsection{Empirical Review on Management Support and Innovativeness}

Al Shaar et al. [3] reported that top management support positively impacted on innovativeness (product innovation, and process innovation). This is due to the important role played by top management in providing the supportive organisational climate for innovation. The study focused on identifying the direct and indirect effect of top management support on innovation through synergy between the organisational structure and information technology. It adopted a survey research design and structural equation modeling (SEM) as data analysis tool.

Similarly, Nafie et al. [16] examined the relationship between organisational climate, corporate entrepreneurship and organisational performance. It focused on the impact of top management support on corporate entrepreneurship as one of its objectives, using survey research design and Generalized Structured Component Analysis (GSCA) in analysing data. The study found that management support and corporate entrepreneurship were positively related. Research along this same line by Kassa and Raju [12] indicated that there was a significant positive correlation between management support and innovative behaviour. The study, however, concluded that the organisational and managerial factors in the Ethiopian leather footwear sector were not supportive of innovation.

Further still, Hornsby et al. [7] reported a moderate correlation between management support and innovativeness in their assessment of organisational climate that promotes and facilitates corporate entrepreneurship behaviour in firms using the corporate entrepreneurship assessment instrument (CEAI). In the same vein, Ryan and Tipu [26] examined the leadership effect on innovation propensity using exploratory and confirmatory factor analysis to assess the CEAI instrument, and structural equation modeling (SEM) to analyse collected data. Results showed that management support (active leadership style) had a strong and significant positive effect on innovativeness. This management function will help in the achievement of their profit objective (Omankhanlen, Ilori and Isibor [22].

Although Kassa and Raju [12] revealed that there was a significant positive correlation between management support and innovative behaviour, they also reported that contextual factors in the Ethiopian leather footwear sector were not supportive of innovation, suggesting that contextual factors are involved in the relationship between management support and innovativeness.

\subsection{Summary Table of Gaps in}

\section{Literature}

Table 1: Gap One: Management Support and Innovativeness

\begin{tabular}{|c|c|c|c|}
\hline $\mathbf{S} / \mathbf{N}$ & Author(s) & Title & Gap \\
\hline 1 & $\begin{array}{l}\text { Karimi, J. } \\
\text { \& Walter, } \\
\text { Z. [11] }\end{array}$ & $\begin{array}{l}\text { Corporate } \\
\text { entrepreneurship, } \\
\text { disruptive } \\
\text { business model } \\
\text { innovation } \\
\text { adoption, and its } \\
\text { performance: The } \\
\text { case of the } \\
\text { Newspaper } \\
\text { Industry }\end{array}$ & $\begin{array}{l}\text { Future studies } \\
\text { should investigate } \\
\text { how internal } \\
\text { organisational } \\
\text { factors affect CE } \\
\text { dimensions }\end{array}$ \\
\hline
\end{tabular}




\begin{tabular}{|c|c|c|c|}
\hline 2 & $\begin{array}{l}\text { Ferdousi, } \\
\text { S. [5] }\end{array}$ & $\begin{array}{l}\text { Cross-functional } \\
\text { teams for } \\
\text { corporate } \\
\text { entrepreneurship } \\
\text { practices }\end{array}$ & $\begin{array}{l}\text { Future research } \\
\text { should } \\
\text { empirically } \\
\text { investigate how } \\
\text { top management } \\
\text { support and } \\
\text { organisational } \\
\text { politics affect the } \\
\text { efficient } \\
\text { functioning of } \\
\text { cross functional } \\
\text { corporate } \\
\text { entrepreneurship } \\
\text { teams. }\end{array}$ \\
\hline 3 & $\begin{array}{l}\text { Heavey, } \\
\text { C. \& } \\
\text { Simsek, } \\
\text { Z. [6] }\end{array}$ & $\begin{array}{l}\text { Top management } \\
\text { compositional } \\
\text { effects on } \\
\text { corporate } \\
\text { entrepreneurship: } \\
\text { the moderating } \\
\text { role of perceived } \\
\text { technological } \\
\text { uncertainty }\end{array}$ & $\begin{array}{l}\text { Future research is } \\
\text { needed to further } \\
\text { probe the } \\
\text { relationship } \\
\text { between top } \\
\text { management team } \\
\text { size and CE. } \\
\text { Moreover, future } \\
\text { studies could also } \\
\text { examine whether } \\
\text { or not top } \\
\text { management team } \\
\text { social network } \\
\text { has indeed an } \\
\text { unconditional } \\
\text { positive effect on } \\
\text { CE under } \\
\text { different } \\
\text { conditions of } \\
\text { perceived } \\
\text { uncertainty. }\end{array}$ \\
\hline 4 & $\begin{array}{l}\text { Mustafa, } \\
\text { M., } \\
\text { Richards, } \\
\text { J.J., \& } \\
\text { Ramos, } \\
\text { H.M. } \\
\text { [15] }\end{array}$ & $\begin{array}{l}\text { High } \\
\text { performance } \\
\text { human resource } \\
\text { practices } \\
\text { (HPHRP) and } \\
\text { corporate } \\
\text { entrepreneurship: } \\
\text { The mediating } \\
\text { effect of middle } \\
\text { managers' } \\
\text { knowledge } \\
\text { collecting and } \\
\text { donating } \\
\text { behavior }\end{array}$ & $\begin{array}{l}\text { Future studies } \\
\text { should examine } \\
\text { other types of } \\
\text { middle managers' } \\
\text { behaviours such } \\
\text { as, risk-taking, } \\
\text { innovativeness, } \\
\text { perceived } \\
\text { organisational } \\
\text { support and } \\
\text { effective } \\
\text { commitment in in } \\
\text { order to further } \\
\text { explain the } \\
\text { relationship } \\
\text { between HPHRP } \\
\text { and corporate } \\
\text { entrepreneurship. }\end{array}$ \\
\hline
\end{tabular}

Source: Researcher's Literature Review

\section{$3 \quad$ Methodology}

\subsection{Research Design}

Principally, this study aimed to provide additional insight on the effect of firm's organisational climate on corporate entrepreneurship in an emerging economy context predicated on selected flour milling companies (operators in the manufacturing sector) in Nigeria. The study employed survey research design. This type of research design allows generalization to be made about a large population when representative samples were drawn. Survey research design was used in this study for its economy, rapid data collection and ability to understand the characteristics of the population under study. The fact that this study was quantitative in nature and involved an attempt to establish causal relationship between variables, made the use of survey research design appropriate.

\subsection{Population}

The target population of the study consisted of a total of 5,362 full time staff of Flour Mills Nigeria Plc, Honeywell Flour Mills Plc, and Dangote Flour Mills Plc. The total number of staff for each of the selected flour milling companies in Nigeria was as follows.

\section{Table 3.1: Target Population}

\begin{tabular}{|c|l|r|}
\hline S/N & \multicolumn{1}{|c|}{ Company } & Number of Staff \\
\hline 1 & Flour Mills of Nigeria Plc & 3,393 \\
\hline 2 & Honeywell Flour Mills Plc & 844 \\
\hline 3 & Dangote Flour Mills Plc & 1,125 \\
\hline & Total & 5,362 \\
\hline
\end{tabular}

Sources: Flour Mills of Nigeria Plc Annual Report and Accounts, 2016; Honeywell Flour Mills Plc Annual Report and Accounts, 2016; Dangote Flour Mills Plc Annual Report and Accounts, 2016

Table 3.2: Composition of the Sample Frame

\begin{tabular}{|c|l|r|r|r|}
\hline S/N & Company & \multicolumn{1}{|c|}{$\begin{array}{c}\text { Managerial } \\
\text { Staff }\end{array}$} & \multicolumn{1}{|c|}{$\begin{array}{c}\text { Non- } \\
\text { managerial } \\
\text { Staff }\end{array}$} & Total \\
\hline 1 & $\begin{array}{l}\text { Flour Mills } \\
\text { of Nigeria } \\
\text { Plc }\end{array}$ & 803 & 2,178 & 2,981 \\
\hline 2 & $\begin{array}{l}\text { Honeywell } \\
\text { Flour Mills } \\
\text { Plc }\end{array}$ & 59 & 300 & 359 \\
\hline 3 & $\begin{array}{l}\text { Dangote } \\
\text { Flour Mills } \\
\text { Plc }\end{array}$ & 41 & 821 & 862 \\
\hline & Total & 903 & 3,299 & 4,202 \\
\hline
\end{tabular}

Sources: Flour Mills of Nigeria Plc Annual Report and Accounts, 2016; Honeywell Flour 
Mills Plc Annual Report and Accounts, 2016; Dangote Flour Mills Plc Annual Report and Accounts, 2016

\subsection{Sample size and sampling Technique} The sample size of this research was based on the Yamane formula on sample size determination. The use of the formula enabled inferences to be drawn about the population through conclusions from the sampled survey. The formula is:

$$
\mathrm{n}=\frac{\mathrm{N}}{1+\mathrm{N}(\mathrm{e})^{2}}
$$

Where: $\mathrm{n}=$ Sample Size, $\mathrm{N}=$ Population $=5362$, $\mathrm{e}=$ Allowable error $\quad=0.05$

Hence,

$$
\frac{5362}{1+5362(0.05)^{2}}
$$

$\mathrm{n}=372$ respondents

The study adopted probability sampling technique in the selection of respondents, because of the intention to draw inferences from the sample to make generalisations about the selected flour milling companies in Nigeria, and by extension, Nigeria's flour milling industry. To this end, stratified and simple random sampling methods were engaged for the study. The three-selected flour milling companies were classified as strata, because they possess unique characteristics in terms of employee size, cultural orientation, market capitalisation, and market share.

Table 3.3: Stratified Distribution of Research Questionnaire

\begin{tabular}{|c|l|c|c|c|}
\hline $\mathbf{S} /$ & \multicolumn{1}{|c|}{$\begin{array}{c}\text { Compan } \\
\text { y }\end{array}$} & $\begin{array}{c}\text { Numbe } \\
\text { r of } \\
\text { Staff }\end{array}$ & $\begin{array}{c}\text { Proportio } \\
\mathbf{n}\end{array}$ & $\begin{array}{c}\text { Allocated } \\
\text { Questionnai } \\
\text { re }\end{array}$ \\
\hline 1 & $\begin{array}{l}\text { Flour } \\
\text { Mills of } \\
\text { Nigeria } \\
\text { Plc }\end{array}$ & 3,393 & $63 \%$ & 234 \\
\hline 2 & $\begin{array}{l}\text { Honeywe } \\
\text { ll Flour } \\
\text { Mills Plc }\end{array}$ & 844 & $16 \%$ & 60 \\
\hline 3 & $\begin{array}{l}\text { Dangote } \\
\text { Flour } \\
\text { Mills Plc }\end{array}$ & 1,125 & $21 \%$ & 78 \\
\hline & Total & 5,362 & $100 \%$ & 372 \\
\hline
\end{tabular}

\subsection{Method of Data Collection}

Based on the objectives of the study and the literature reviewed, primary data were collected through a structured six-point Likert scale questionnaire, ranging from 1 "strongly disagree" to 6 "strongly agree". The questionnaire was administered to 372 respondents that were randomly selected from the strata among the managerial and nonmanagerial staff of the three-selected flour milling companies.

\subsection{Model Specification}

The following algebraic simple regression model will guide this study $\mathrm{Y}$ is the dependent variable i.e. Corporate Entrepreneurship (CE). Where: $y_{1}$ $=$ Innovativeness $(\mathrm{INV}), \mathrm{x}_{1}=$ Management Support (MGS), $\beta_{2}=$ regression co-efficient of $\mathrm{x}_{2}, \mathrm{x}_{2}=$ Reward System (RWS), ei = variance in the equation

Functional Relationship of the Research Model: Hypothesis 1:

$\mathrm{INV}=\mathrm{a}_{0}+\beta_{1} \mathrm{MGS}+\mathrm{ei}$

\section{A-priori Expectations}

\begin{tabular}{|c|c|l|}
\hline S/N & \multicolumn{1}{|c|}{ Models } & A-priori expectations if: \\
\hline$H_{01}$ & $\begin{array}{c}\text { INV } \\
\mathrm{a}_{0}+\beta_{1} \mathrm{MGS}+\mathrm{ei}\end{array}$ & $\begin{array}{l}\beta \neq 0: \mathrm{p} \leq 0.05: \mathrm{H}_{\mathrm{o}} ; \text { will be } \\
\text { rejected }\end{array}$ \\
\hline
\end{tabular}

\section{Interpretation \& Presentation \\ 4.1 Hypothesis Testing}

$\mathbf{H}_{01}$ : Management support does not have a significant effect on innovativeness in the selected flour milling companies in Lagos State.

Simple linear regression was used to test the hypothesis. The outcomes of the analysis are presented in Tables 4.2 - 4.4.

\begin{tabular}{|c|c|c|c|c|}
\hline \multicolumn{4}{|c|}{ Table 4.1 Model Summary } \\
\hline Model & $\mathbf{R}$ & $\begin{array}{c}\mathbf{R} \\
\text { Square }\end{array}$ & $\begin{array}{c}\text { Adjusted } \\
\text { R Square }\end{array}$ & $\begin{array}{c}\text { Std. Error } \\
\text { of the } \\
\text { Estimate }\end{array}$ \\
\hline 1 & $.620^{\mathrm{a}}$ & .385 & .381 & 1.718 \\
\hline \multicolumn{5}{|l}{} \\
\hline
\end{tabular}

The result of the model summary shown in Table 4.2 indicate that $\mathrm{R}=.620$ and $\mathrm{R}^{2}=.385$. This implies that 38.5 percentage variations in innovativeness could be explained by a unit change in management support. It also shows that the remaining $61.5 \%$ was explained by other variables. This, therefore, signifies that a unit change in management support culminate in the 
same unit variation in innovativeness in the selected flour milling companies in Nigeria.

\begin{tabular}{|c|c|c|c|c|c|c|}
\hline \multicolumn{7}{|c|}{ Table 4.2 ANOVA } \\
\hline & Model & $\begin{array}{c}\text { Sum of } \\
\text { Squares }\end{array}$ & df & $\begin{array}{c}\text { Mean } \\
\text { Square }\end{array}$ & $\mathbf{F}$ & Sig. \\
\hline \multirow[t]{3}{*}{\begin{tabular}{|l|}
1 \\
\end{tabular}} & Regression & 556.958 & 1 & 556.958 & 188.671 & $.000^{\mathrm{b}}$ \\
\hline & Residual & 891.513 & 302 & 2.952 & & \\
\hline & Total & 1448.471 & 303 & & & \\
\hline
\end{tabular}

The one-way ANOVA result $[\mathrm{F}(1,302)=$ 188.671, $\mathrm{p}<.01$ ] in Table 4.3, shows that the model is statistically significant at 1 percent level of significance, which is less than the 5 percent a-priori expectation for the study. Besides, the residual mean square of 2.952 further demonstrate the existence of variation in the regression model. This means that the overall regression model significantly predicted the effect of management support on innovativeness in the selected flour milling companies in Nigeria.

\begin{tabular}{|c|c|c|c|c|c|}
\hline \multicolumn{6}{|c|}{\begin{tabular}{|l|} 
Table 4.3 Coefficients \\
\end{tabular}} \\
\hline \multirow[t]{2}{*}{ Model } & \multicolumn{2}{|c|}{$\begin{array}{c}\text { Unstandardiz } \\
\text { ed } \\
\text { Coefficients }\end{array}$} & \multirow{2}{*}{\begin{tabular}{|c|}
$\begin{array}{c}\text { Standardize } \\
\text { d } \\
\text { Coefficients }\end{array}$ \\
Beta \\
\end{tabular}} & \multirow[t]{2}{*}{ t } & \\
\hline & $\mathbf{B}$ & $\begin{array}{l}\text { Std. } \\
\text { Error }\end{array}$ & & & \\
\hline (Constant) & $\begin{array}{c}- \\
6.493\end{array}$ & 1.587 & & $\begin{array}{c}- \\
4.091\end{array}$ & $\begin{array}{c}.00 \\
0\end{array}$ \\
\hline $\begin{array}{l}\text { Manageme } \\
\text { nt support }\end{array}$ & .776 & .057 & .620 & $\begin{array}{c}13.61 \\
4\end{array}$ & $\begin{array}{c}.00 \\
0\end{array}$ \\
\hline
\end{tabular}

Source: Computed Based on Survey Data (2018)

Table 4.3 shows that management support significantly predicted innovativeness with an estimated coefficient $($ Beta $)=.620, \mathrm{p}<.01$. The unstandardized coefficients $(\beta=.776, p<.01)$ with a constant $\alpha=-6.493$ indicate that the model $\mathrm{y}_{1}=-6.493+.776$ (management support) is significantly fit. This further confirms that management support significantly affect innovativeness in the selected flour milling companies in Nigeria.

Tables 4.1, 4.2, and 4.3, shows the results of simple regression that was calculated to determine the effect of management support on innovativeness in the selected flour milling companies in Nigeria. Preliminary analysis was performed to ensure that there was no violation of the assumptions of normality and linearity. A significant regression equation was found $[\mathrm{F}(1,302)=188.671, \mathrm{p}<.01]$ with an $\mathrm{R}=.620, \mathrm{R}^{2}$
$=.385$, Adjusted $\mathrm{R}^{2}=.381$. The regression equation indicated that the effect of management support as the predictor variable on innovativeness as the dependent variable was significant at $\mathrm{p}<.01$, which is less than $\mathrm{p}<.05$. Moreover, the $\mathrm{R}$ value of 620 , reveals that there is a high correlation between management support and innovativeness. The $\mathrm{R}^{2}$ value indicates that .385 total variations in innovativeness can be explained by variation in management support. This implies that the explanatory power of management support on innovativeness is $38.5 \%$.

The adjusted R-squared of .381 percent retention factors explained only about $38 \%$ of the variation in innovativeness. The $F$ value of $[F(1,302)=188.671]$ in Table 4.14 shows that the overall regression model is significant, hence it has some explanatory value. This indicated that there is a significant relationship between the predictor variable (management support) and innovativeness.

\section{Decision:}

Based on the summary results of linear regression analysis of management support and innovativeness in Tables 4.1, 4.2 and 4.3 which indicated $[\mathrm{F}(1,302)=188.671, \mathrm{p}<0.01], \mathrm{R}=.620$, $\mathrm{R}^{2}=.385$, Adj $\mathrm{R}^{2}=.381$, and estimated coefficient (Beta) .620, the null hypothesis which states that management support has no significant effect on innovativeness in the selected flour milling companies was rejected, while the alternative hypothesis which states that management support has significant effect on innovativeness was accepted. This implies that for the companies to achieve sustainable competitive advantage and survive, innovativeness at both the individual and organisational levels should be encouraged by management. This would involve improved management's receptiveness to innovative ideas, sustained encouragement of experimental projects, continuous provision of necessary resources for innovative projects, tolerance for experimental project failures, flexibility in enforcing established procedures, and providing required leadership for innovative ventures.

The regression result shows that the explanatory power of management support on innovativeness is $38.5 \%$. This explanatory power has important implications for the selected flour milling 
companies, because it validates the descriptive statistical results in Table 4.1, which indicated that there was partial agreement amongst the respondents that management of the selected companies encouraged idea generation and creativity in seeking competitive advantage. It is reflective of the fact that perceived management support for innovativeness amongst employees is in- between and this has implications for the rate of idea generation and creativity at the individual level. The descriptive statistics on innovativeness suggested that there is a general agreement that innovativeness is prevalent in the companies.

\section{Conclusion \\ 5.1 Conclusion}

Based on empirical findings, it is averred that apart from the importance of management support in terms of addressing challenges encountered by employees in pursuit of innovative projects, moral backing and motivation in the development of innovative behaviour and perceived management's level of tolerance for mistakes, as well as belief in the importance of innovation for organisational growth are important ingredients to innovative behavior Kassa and Raju [12].

The findings of this study aligned with these assertions. Evidence from the analysed data suggested that management support has a significant positive effect on innovativeness. It was observed from the descriptive statistics that the management of the selected companies were perceived to display some level of disposition towards encouraging innovative behaviour through acceptance of innovative ideas and tolerance of mistakes as well as provision of the required leadership and moral support in terms of motivation and resources for innovative projects.

Thus, in line with the specific objective of this study and the related research question, the effect of management support on innovativeness was examined and the empirical result indicated that management support has a significant positive effect on innovativeness in the selected flour milling companies. The outcome of this study aligns with the results of some prior studies to underscore management support as a vital facilitator of innovative behavior in existing businesses through the provision of psychological and physical resources that people require in taking entrepreneurial actions.

\subsection{Recommendation}

The study recommended that management should nurture an organizational management support that encourages entrepreneurial behavior by making organizational design and development a continuous focus.

In addition, research and development on modern business models are adopted and used which have turned out to be successful in emerging markets, this should be encouraged and used in Nigeria to improve on the countries entrepreneurial output.

Moreover, difficulties encountered by entrepreneurs and the solutions that are used to overcome them should be documented for future reference.

Lastly, there should be a synergy between management and those in research and development since the study has shown that management support has a positive effect on innovativeness in Nigeria businesses, which can help during Corporate restructuring. This in its simplest form, can be described as the process of changing the structure (managerial, financial, etc.) of a business organization to enhance its performance. (Okoye, Omankhanlen, Okoh \& Ibileke [20]

\section{Acknowledgement}

The authors wish to acknowledge the financial support offered by Covenant University in actualization of this research work for publication.

References

[1]. Abrell, C., Rowold, J., Weibler, J., \& Moenninghoff, M.. Evaluation of a long-term transformational leadership development program. German Journal of Human Resource Management. 25 (2011) 205-224.

[2]. Aggeri, F., \& Segrestin, B.. Innovation and project development: An impossible equation? Lessons from an innovative automobile project development. R\&D Management. 37 (2007) 37-47.

[3]. Al Shaar, E. M., Khattab, S.A., Alkaied, R.N., \& Manna, A.Q.. The effect of top 
management support on innovation: The mediating role of synergy between organizational structure and information technology. International Review of Management and Business Research. 4 (2015) 499-513.

[4]. Atalay, M., Anafarta, N., \& Sarvan, F., The relationship between innovation and firm performance: An empirical evidence from Turkish automotive supplier industry. Procedia - Social and Behavioral Sciences. 75 (2013) 226235.

[5]. Ferdousi, S. Cross-functional teams for corporate entrepreneurship practices. The ISM Journal of International Business. 1 (2012) 2-25.

[6]. Heavey, C., \& Simsek, Z., Top management compositional effects on corporate entrepreneurship: The moderating role of perceived technological uncertainty. Journal of Product Innovation Management. 46 (2013) 1289-1314.

[7]. Hornsby, J.S., Kuratko, D.F., Holt, D. T., \& Wales, W.J. Assessing a measurement of organizational preparedness for corporate entrepreneurship. Journal of Product Innovation Management. $30 \quad$ (2013) 937-955.

[8]. Ikon, M. A., \& Nwankwo, C. N. (2016). Production planning and profitability of selected manufacturing firms in Nigeria. International Journal of Business and Management Review. 4 (2016) 11-32.

[9]. Imran, R., Saeed, T., Anis-ul-Haq, M., \& Fatima, A. Organizational climate as a predictor of innovative work behavior. African Journal of Business Management. 4 (2010). 3337-3343.

[10]. Kang, J.H., Matusik, J.G., Kim, T., \& Phillips, J.M., Interactive effects of multiple organizational climates on employee innovative behavior in entrepreneurial firms: A cross-level investigation. Journal of Business Venturing. 31 (2016). 628-642.

[11]. Karimi, J., \& Walter, Z.. Corporate entrepreneurship, disruptive business model innovation adoption, and its performance: The case of the Newspaper Industry, Long Range Planning. 49 (2016) 342-360.

[12]. Kassa, A. G., \& Raju, R.S. Corporate entrepreneurship and innovation. European Journal of Business and Management, 6 (2014). $50-67$.

[13]. KPMG, Wheat-based Consumer Foods in Nigeria (2016). Retrieved from https://assets.kpmg.com/content/dam/kp $\mathrm{mg} / \mathrm{co} / \mathrm{pdf} / 005$-wheat-based-consumerfoods-in-nigeria.pdf

[14]. Kra'snicka, T., Głód, W., Wronka-Po'spiech, M. Management innovation, pro-innovation organisational culture and enterprise performance: Testing the mediation effect. Review Managerial Science, 12 (2018) 737-769

[15]. Mustafa, M., Richards, J.J., \& Ramos, H.M. High performance human resource practices (HPHRP) and corporate entrepreneurship: The mediating effect of middle managers' knowledge collecting and donating behaviour. Asian Academy of Management Journal, 18 (2018) 17-36.

[16]. Nafie, N.A.L., Nimran, U., Musadieq, M., \& Suyadi, I. Organizational internal factors, corporate entrepreneurship and organizational performance. European Journal of Business and Management. 6 (2014) 83-97.

[17]. Njoku, M.E., \& Kalu, A.O.U. Effective supply chain management: A strategic tool for profitability enhancement in the competitive marketing environment (an empirical evidence in the Nigerian food and beverage industry 2005-2014). European Journal of Business and Management. 7 (2015) 234-248.

[18]. Oke, A. \& Dawson, P. Contextualising workplace stress: the experience of bank employees in Nigeria. Faculty of Commerce - Papers (Archive). University of Wollongong, Research Online (2008). 
[19]. Okoye L.U, Omankhanlen A.E.,Okoh J.I.\& Ibileke E. 2018 Corporate Restructuring and Corporate Performance in Nigeria: Insight from the Banking Sector.32 ${ }^{\text {nd }}$ International Business Information Management Association IBIMA

[20]. Okoye L.U, Omankhanlen,A.E Okoh J.I \& Areghan A.I. Technology-Based Financial Services Delivery and Customer Satisfaction: A Study of The Nigerian Banking Sector International Journal of Civil Engineering and Technology (IJCIET) 9 (2018)

[21]. Olughor, R.J. Corporate entrepreneurship and employee retention strategies in Nigerian Telecommunication Industry. European Journal of Business and Social Sciences, 3 (2014). 9-23.

[22]. Omankhanlen A.E.,Ilori N \& Isibor A. Monetary policies and the achievement of bank profit objective. $32^{\text {nd }}$ International Business Information Management Association IBIMA (2018)

[23]. Probst, T.M. Organizational safety climate and supervisor safety enforcement: Multilevel explorations of the causes of accident underreporting. Journal of Applied Psychology, 100 (2015). 1899-1907.

[24]. Rangarajan, D., Jones, E., \& Chin, W. Impact of sales force automation on technology-related stress, effort, and technology usage among salespeople. Industrial Marketing Management, 34 (2005). 345-354.

[25]. Rubera, G., \& Kirca, A. Firm innovativeness and its performance outcomes: A meta-analytic review and theoretical integration. Journal of Marketing, 76 (2012) 130-147.

[26]. Ryan, J.C., Syed, A.A., \& Tipu, S.A.. Leadership effects on innovation propensity: A two-factor full range leadership model. Journal of Business Research, 66 (2013) 2116-2129.

[27]. Scott, S.G., \& Bruce, R.A. Determinants of innovative behavior: A path model of individual innovation in the workplace. Academy of Management Journal, 37 (1994) 580607.

[28]. Tsado, E., \& Gunu, U. Managers' perception of internal factors and their effect on corporate entrepreneurship: The case of Nigerian manufacturing industry. ACTA UNIVERSITATIS DANUBIUS, 12 (2016). 240-253.

[29]. van Wyk, R.V., \& Adonisi, M. Antecedents of corporate entrepreneurship. South Africa Journal of Business Management, 43 (2012) 6578.

[30]. Yuan, F., \& Woodman, R. W. Innovative behavior in the workplace: The role of performance and image outcome expectations. Academy of Management Journal, 53 (2010). 323342. 